\title{
Integrated Marketing Communications and International Advertising in Kosovo
}

\author{
Msc. Halit Karaxha (PhD. Cand.) \\ halitkaraxhaekonomik@hotmail.com
}

\section{Msc. Hidajet Karaxha (PhD. Cand.)}

hidajeti_21@hotmail.com

\author{
Prof. Dr. Arjan Abazi
}

abazi_a@hotmail.com

Doi:10.5901/ajis.2015.v4n1s2p115

\section{Abstract}

\begin{abstract}
Integrated Marketing Communications are composed of ads, sales promotion, personal sale, direct sale and public relations. The main challenges in Integrated Marketing Communications are the recognition of communication means of mixed marketing, the advantages of International Advertising, the methods of determining promotional budgets, the steps in developing an effective communication of marketing. Integrated Marketing Communications are means with which the firms try to remind the consumers about their products and services. A very important challenge is the measurement of marketing's results and the analysis about what percent of these costs are reversed or have exceeded beyond the margin of spending. The firms have to invest more in Integrated Marketing Communications, where the importance of investments is seen from two points of view: the growth of profit and their role towards the public. International advertisements have a great impact in introducing the products and services in international markets. The costs of international ads have changed depending on the periods of economic development; the periods of global developments are associated with the increase of advertisements costs, while the periods of global recessions are associated with the decrease of these costs. In this paper it is explained how the importance of marketing's integrated communications affects the growth of sales and the connection with the public and the role of international ads in promoting new products in international markets. The first part of the paper is composed of reviewing the adequate literature and the second part has to do with the part of the study about Integrated Marketing Communications and international advertisements. Primarily data was realized through questionnaires, through direct contact with marketing managers, general managers, owners and directors of companies that have sufficient knowledge about their companies.
\end{abstract}

Keywords: Integrated Marketing Communications, International Advertising, International markets

\section{The Review of Literature}

\subsection{Integrated Marketing Communications}

Integrated Marketing Communications (IMC) are composed of advertisements, sale promotions, personal sale, direct sale and public relations (Cateora \& Gilly \& Graham, 2011). Integrated communications of marketing (IMC) are being practiced all over the world at a very high range. IMC is connected with some positive results of the brand, client's satisfaction, brand loyalty, brand's positive image, the growth of sales and cost reduction (Saeed \& Naeem \& Bilal \& Naz, 2013). Integrated Marketing Communications is a powerful measure that has an impact in the effectiveness of the development and implementation of marketing's communication (Shakeel-Ul-Rehman \& Ibrahim, 2011). IMC programs have to be in accordance with company's policies, and have to be part of the management and all other aspects of company's communication, informing the company about corporation's brands which have to be in accordance with all the brands of the company's markets (Percy, 2008). Integrated Marketing Communications is a process of communication with customers about the brand's capital through different measures of communication. Except the used communication methods, the main rule is that the message flows have to be in the same directions and have the same objectives (Suwantara \& Taechamaneesatit, 2012). The integrated communications of marketing include the identification of the targeted audience and the design of a promotional program which has to be well-coordinated in order to receive 
the desired response from the audience. Often, marketing's communications focus on in immediately receiving the information, in the image or in the preference goals of the targeted market. Today, marketing specialists are moving towards naming the communications as time management in the relations with clients (Kotler \& Armstrong, 2011). Anyway, maybe the clearer definition for the Integrated Marketing Communications is given by the American Association of Advertising Agencies (1993): The integrated communication of marketing is a concept of planning the marketing communication that recognizes an added value of a comprehensive and strategic plan that evaluates the roles of a variety of communication disiplines and combines them to ensure clarity, consistency and a maximal communication impact through an ongoing and discrete integration of messages (Baker, 2003).

\subsection{Sales Promotions in International Markets}

Sales promotions are marketing activites that stimulate consumer purchases and improve retail sales. Sampes, coupons, gifts, promotional products, competitions, lotaries, the sponsorship of special events such as concerts, olympiads, fairs and points of purchase are measures to promote sales (Cateora \& Gilly \& Graham, 2011).

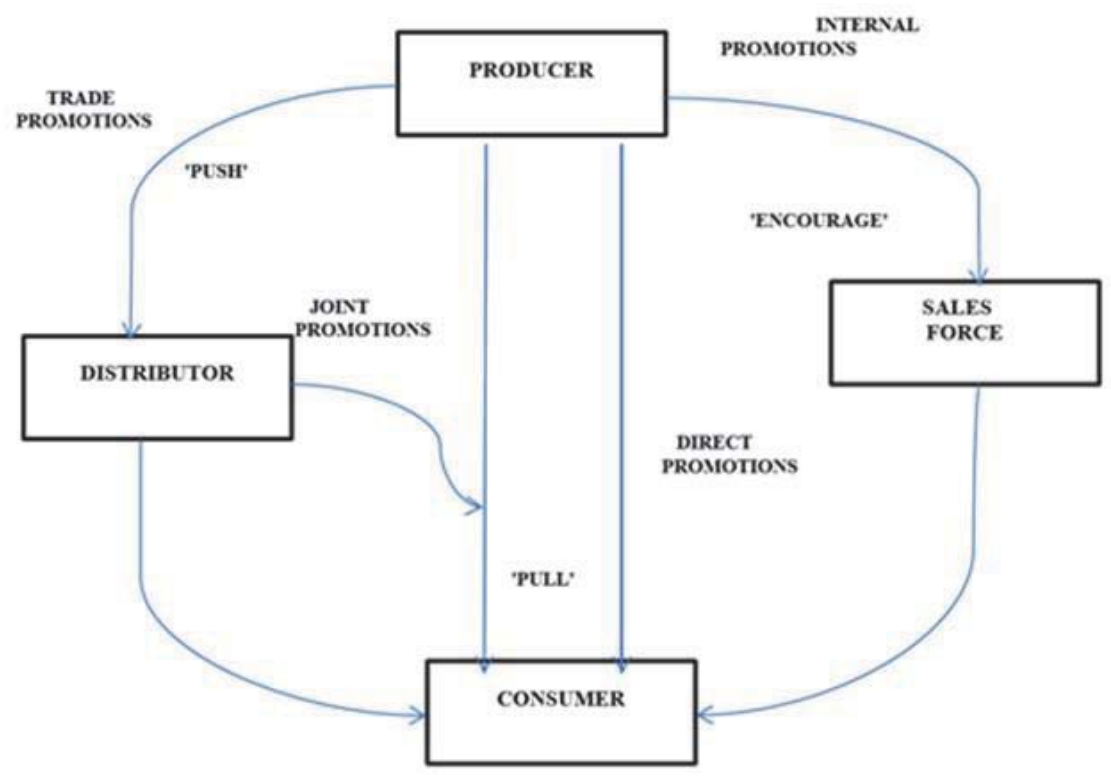

Source: Baker (2003).

Sales promotion are defined as marketing activities that are usually specific for a period of time, that encourage a direct response from the consumers or market mediators, through the offer of additional benefits (Baker, 2003). Sales promotion are a direct incentive that offers additional values for the product, distributors, consumers and the main objective is to achieve an immediate sale. First, promotional sales include a variety of incentives that provides additional incentive to buy. This incentive is usually the main factor in a promoting program; it can be a coupon or a reduction of the product's cost, the opportunity to enter a competition or lottery, reimbursement or discount in the products price (Belch \& Belch, 2003). 


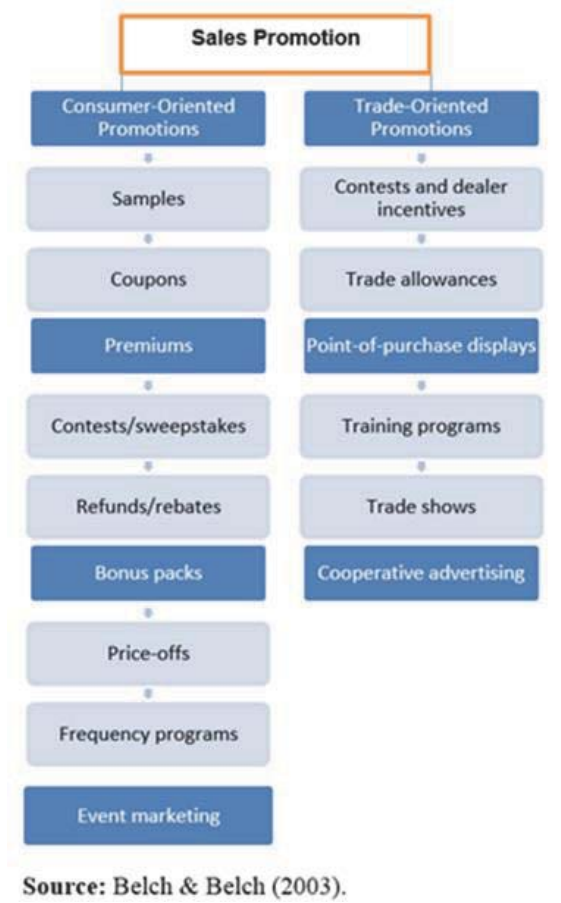

Figure 2: Types of sales promotion activities

In general, more than the half of marketing communication costs goes to the promotion of trade. A trade promotion is a program of discounts that aims the growth of retail sales (Percy, 2008).

\section{International Advertising}

The growth of International Advertising costs has slowed, especially during the global recession of 2008-2009. An important study has showed that advertisement costs are generally cyclic (Cateora \& Gilly \& Graham, 2011).

Table 1: Top 20 Global Advertisers (\$ millions)*

\begin{tabular}{ccllcc}
\hline 2008 & 2007 & Advertiser & Headquarters & 2008 & Percent Change \\
\hline 1 & 1 & Procter \& Gamble Co. & Cincinnati & $\$ 9,731$ & $0.0 \%$ \\
2 & 2 & Unilever & London/Rotterdam & 5,717 & 1.8 \\
3 & 3 & L'Oreal & Clichy, France & 4,040 & 10.8 \\
4 & 4 & General Motors & Detroit & 3,674 & 5.4 \\
5 & 5 & Toyota Motor Corp. & Toyota City, Japan & 3,203 & -3.2 \\
6 & 8 & Coca-Cola Co. & Atlanta, GA & 2,673 & 13.5 \\
7 & 7 & Johnson \& Johnson & Neë Brunsëick, NJ & 2,601 & 4.5 \\
8 & 6 & Ford Motor Co. & Detroit & 2,448 & -14.0 \\
9 & 11 & Reckitt Benckiser & Slough, Berkshire, UK & 2,369 & 13.0 \\
10 & 9 & Nestle & Vevey, Sëitzerland & 2,314 & 1.0 \\
11 & 12 & Volksëagen & Ëolfsburg, Germany & 2,309 & 15.4 \\
12 & 10 & Honda Motor Co. & Tokyo & 2,220 & 4.6 \\
13 & 15 & Mars Inc. & McLean, VA & 1,998 & 5.0 \\
14 & 19 & McDonald's Corp. & Oakbrook, IL & 1,968 & 6.9 \\
15 & 14 & Sony Corp. & Tokyo & 1,851 & -3.3 \\
16 & 17 & GlaxoSmithKline & Brentford, Middlesex, UK & 1,831 & -3.2 \\
17 & 20 & Deutsche Telekom. & Bonn, Germany & 1,812 & 7.7 \\
18 & 18 & Kraft Foods & Northfi eld, IL & 1,792 & -2.7 \\
19 & 16 & Nissan Motor Co. & Tokyo & 1,716 & -9.7 \\
20 & 21 & Ëalt Disney Co. & Burbank, CA & 1,586 & -2.0 \\
\hline
\end{tabular}

* Figures are U.S. dollars in millions and are AdvertisingAge estimates.

Source: (Cateora \& Gilly \& Graham, 2011). 
Table 2: Top 100 Advertisers' Global Spending by Category (\$ millions)

\begin{tabular}{|c|c|c|c|}
\hline Category & 2008 & Percent Change from 2007 & Advertiser Count \\
\hline Automotive & $\$ 25,613$ & $0.1 \%$ & 18 \\
\hline Personal care & 25,480 & 3.4 & 11 \\
\hline Food & 11,914 & 4.9 & 9 \\
\hline Drugs & 10,323 & 1.8 & 11 \\
\hline Entertainment \& Media & 9,608 & -1.8 & 7 \\
\hline Retail & 5,968 & 17.8 & 8 \\
\hline Restaurants & 4,289 & 9.6 & 4 \\
\hline Soft drinks & 4,064 & 5.3 & 2 \\
\hline Telephone & 3,974 & 2.7 & 4 \\
\hline Cleaners & 3,829 & 10.7 & 3 \\
\hline Beer, ëine, \& liquor & 2,681 & 2.1 & 5 \\
\hline Financial & 2,595 & -9.0 & 6 \\
\hline Electronics \& imaging & 2,100 & 8.9 & 3 \\
\hline Technology & 2,035 & -11.5 & 4 \\
\hline Electronics & 1,846 & 20.7 & 2 \\
\hline Toys & 1,607 & 12.8 & 3 \\
\hline
\end{tabular}

Source: Cituar: (Cateora \& Gilly \& Graham, 2011).

Table 1 and 2 illustrate the world's largest advertisers by expenditure and product's categories. Even though car companies dominate the lists, Procter \& Gamble was a world champion of costs. From all the elements of mix marketing, the decisions that include advertisements are the ones that affect more often the cultural differences of different markets. We have to adjust to the client's culture, their style, value system, attitudes, beliefs and perceptions, because the function of advertisements is to interpret or translate the product values in the aspect of the consumer needs and desires. The agreement for a more unique international advertising campaign of markets is a challenge that is getting in front of international marketing. The framework and concept of international advertisements are essentially the same in every country (Cateora \& Gilly \& Graham, 2011). Standardized advertisements have raised the financial and strategic performance of the firms, provided that the internal and external environment is favorable for standardization. There are three general categories of factors that affect the level of advertising standardization that a company hires, and they are: external factors of the environment, strategic factors and the factors that are related to the internal organizational characteristics (Okazaki \&Taylor\& Zou, 2006). The standardization of international advertisements is a marketing strategy adopted by many companies nowadays. Its main priority is related to the reduction of cost and the development of image for an organization and its products in a global range. Unfortunately, this strategy hasn't considered some other important factors for the effectiveness of advertising, such as cultural sensitivity and physical barriers, which are related with the legal and technical regulation of advertisements, even though the adaption of international advertisements can fill these gaps (Ruževičius \& Ruževičiūtè, 2011).

\section{Research Results}

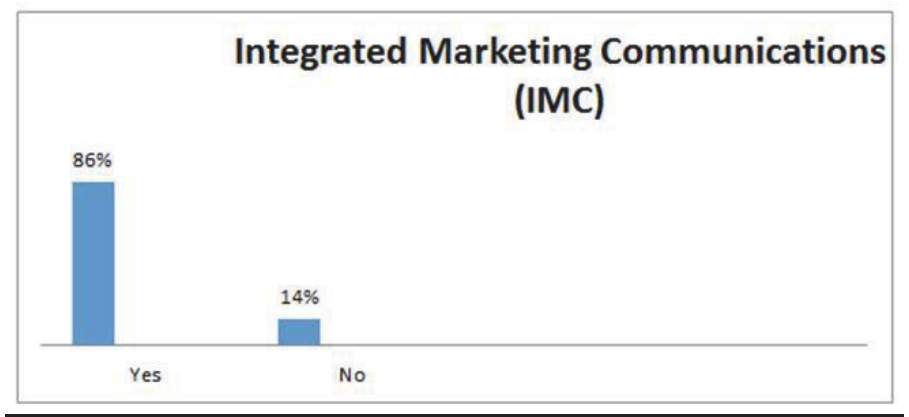

Figure 3: Do you have knowledge about the Integrated Marketing Communications (IMC)

Source: Calculating the authors based on the results of research 
The increasing practice of Integrated Marketing Communications all over the world is increasing the role of IMC. Based on the results, $86 \%$ said that they are informed about the concept of integrated communications of marketing and only $14 \%$ said that they don't know about them. So, based on the research results we can see that most of businesses are familiarized with the concept of IMC.

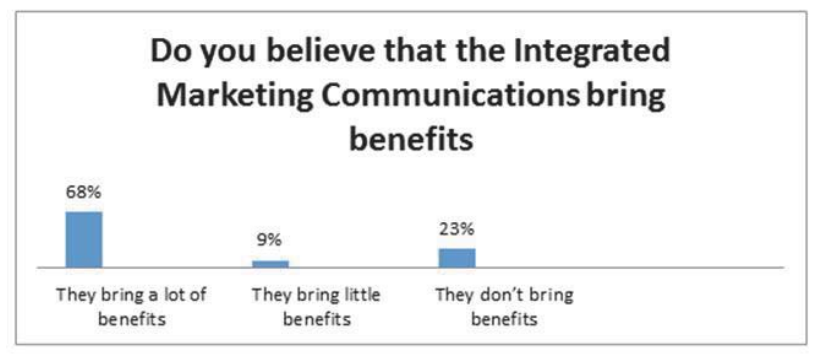

Figure 4: Do you believe that the Integrated Marketing Communications bring benefits

Source: Calculating the authors based on the results of research

Most of the respondents think that the Do you believe that the Integrated Marketing Communications bring benefits, $68 \%$ think that they bring a lot of benefits, $23 \%$ think that they don't bring benefits at all and $9 \%$ think that the integrated communications of marketing bring a little benefits.

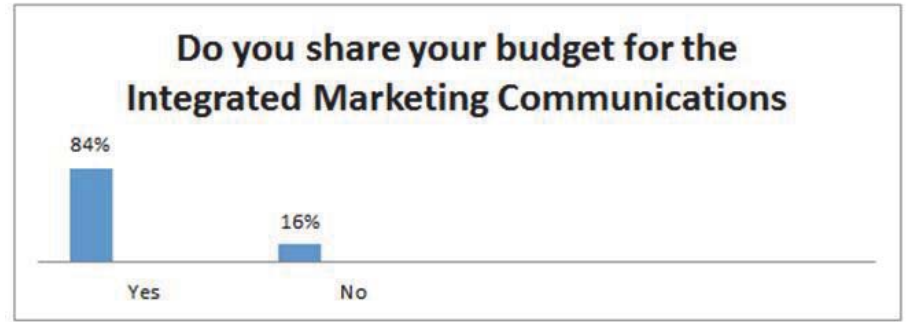

Figure 5: Do you share your budget for the Integrated Marketing Communications

Source: Calculating the authors based on the results of research

From the results we can see a favorable situation because most of the businesses share their funds for the Integrated Marketing Communications, and this allows the businesses to get closer to the consumers and the consumers to be more informed about the company's products, and based on this to realize more sales. From the respondents, $84 \%$ said that they share their budget for the Integrated Marketing Communications and only 16\% said that they don't share their budget for Integrated Marketing Communications, hoping that in the future they will.

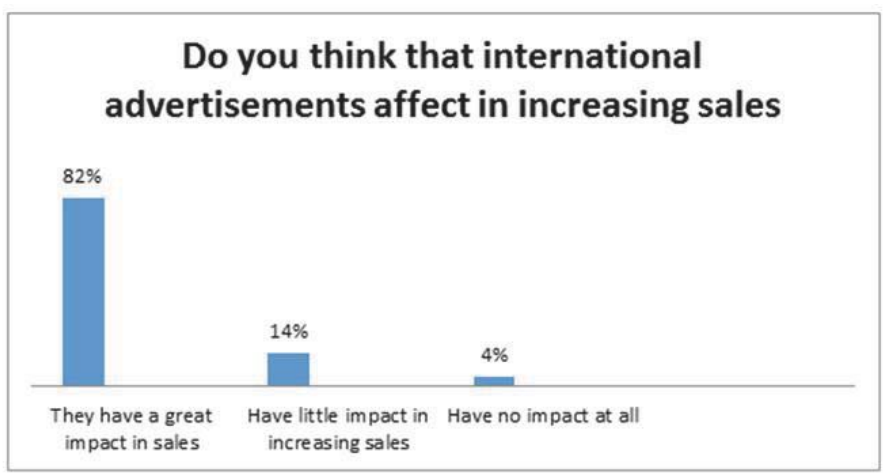

Figure 6: Do you think that international advertisements affect in increasing sales Source: Calculating the authors based on the results of research 
International advertisements have a great impact in consumer's beliefs about the products and services, and also have a positive impact in increasing the sales; therefore many global companies share most of their profit for advertisements. We can see that most of the respondents think that advertisements have a positive impact in increasing sales. $82 \%$ of the respondents think that international advertisements affect in sales growth, 14\% think that international advertisements have a little impact and only $4 \%$ of the respondents think that they have no impact at all.

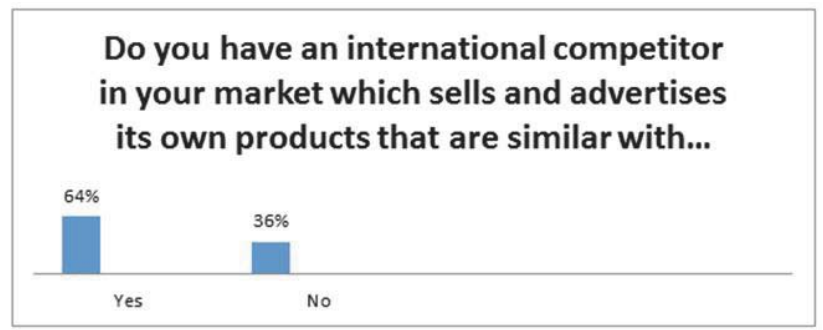

Figure 7: Do you have an international competitor in your market which sells and advertises its own products that are similar with yours

Source: Calculating the authors based on the results of research

Based on the results we can see that many international competitors operate and advertise their products in our country. $64 \%$ of the respondents said that they have international competitors in their market, while $36 \%$ of them said that they don't have international competitors which advertise and sell their products.

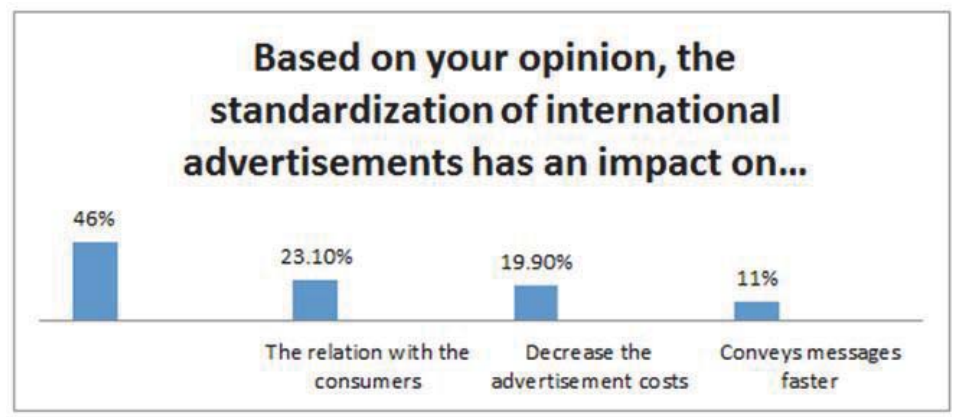

Figure 8: Based on your opinion, the standardization of international advertisements has an impact on increasing Source: Calculating the authors based on the results of research

Based on the results we can see that $46 \%$ of the respondents think that the standardization of international advertisements has an impact in increasing the company's financial and strategic performance, $23.1 \%$ think that the standardization affects the relation with the consumers, $19.1 \%$ of the respondents think that the standardization of international advertisements reduces the advertisement costs and $11 \%$ think that it conveys messages faster.

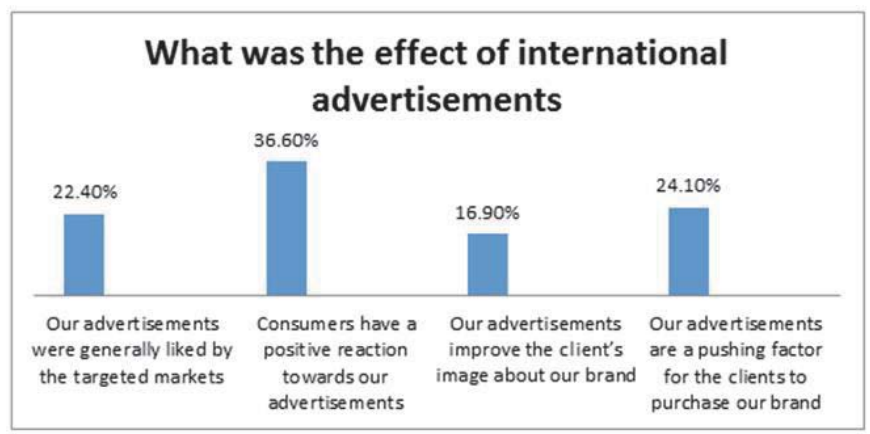

Figure 9: What was the effect of international advertisements

Source: Calculating the authors based on the results of research 
Advertisements have an important impact in increasing businesses performance, in the relation with consumers, improving the brand's image. From the research results, $22.4 \%$ said that international advertisements were generally liked by the targeted markets, $36.6 \%$ said that consumers have a positive reaction towards their advertisements, $16.9 \%$ of the respondents said that their advertisements improve the client's image about their brand and $24.1 \%$ said that their advertisements are a pushing factor for the clients to purchase their brands.

\section{Conclusions and Recommendations}

The Integrated Marketing Communications are measures through which we connect with our clients, bringing them closer to our brands, having more information about our brands, and based on this realizing more profit. It is very hard to know exactly how big the advertisement market is and what percentage goes to newspapers, radios or TV. But this is not the only challenge. Another important challenge is the measurement of the results of Integrated Marketing Communications and the analysis of how much of these costs have been returned or have overcome the costs margin. International advertisement costs are cyclical and are depended on the global economic development. From the research results we can see that most of the respondents are familiar with the concept and importance of Integrated Marketing Communications. We can also notice that most of the businesses share their budget for these communications, which is a very positive factor for the companies that are aiming to increase their performance. The standardization of international advertisements affects in increasing the financial and strategic performance of companies. The advertisements had impact on the relations with the clients, who purchased our brand, the image of which was highly increased. So, as an end, the Integrated Marketing Communications and international advertisements are a safe base in increasing company's performance.

\section{References}

Kotler. P \& Armstrong. G (2011) " Principles of Marketing" 14th Edition, Pearson Prentice Hall

Cateora. P., Gilly. M., Graham. J (2011) " International Marketing " Fifteenth Edition, McGraw-Hill//rwin

Saeed. R., Naeem. B., Bilal. M., Naz. U (2013) " Integrated Marketing Communication " Interdisciplinary Journal of Contemporary Research in Business, vol 5, no 5, p.124-133

Rehman. Sh., Ibrahim. S (2011) "Integrated Marketing Communication and Promotion " International Refereed Research Journal, www.researchersworld.com, Vol.- II, Issue -4, p. 187-191

Percy. L (2008) " Strategic Integrated Marketing Communication " First edition, Published by Elsevier Inc

Suëantara. N., Taechamaneesatit. T (2012) " The Forms of Integrated Marketing Communication that Effect the Brand Equity Perception in Direct Sale System Comparing Thai and Foreign Cosmetics Brand ", DOI: 10.7763/IPEDR. 2012. V50. 13 p.58-62

Baker. M (2003) " The Marketing Book " Fifth Edition, Butterworth-Heinemann

Belch, G., Belch, M. (2003)." Advertising and Promotion, An Integrated Marketing Communications Perpective", Sixth Edition, The McGraë-Hill Companies

Okazaki. S., Taylor. C., Zou. S (2006) " Advertising Standardization's Positive Impact On The Bottom Line " Journal of Advertising, vol. 35, no. 3 (Fall 2006), pp. 17-33., (C) 2006 American Academy of Advertising.

Ruževičius. J., Ruževičiūtè. R (2011) " Standardization and adaptation in international advertising: The concept and case study of cultural and regulatory peculiarities in Lithuania ", Verslo ir teisès aktualijos / Current Issues of Business and Laë, ISSN 18229530 print / ISSN 2029-574X online ,2011, 6(2), 286-301 
